\title{
Mechanism of $\mathrm{Cu}(\mathrm{II})$-catalyzed monochloramine decomposition in aqueous solution
}

\author{
Jun $\mathrm{Fu}^{\mathrm{a}, \mathrm{b}}$, Jiuhui Qu ${ }^{\mathrm{a}, *}$, Ruiping Liu ${ }^{\mathrm{a}}$, Zhimin Qiang ${ }^{\mathrm{a}}, \mathrm{Xu}$ Zhao ${ }^{\mathrm{a}}$, Huijuan Liu ${ }^{\mathrm{a}}$ \\ a State Key Laboratory of Environmental Aquatic Chemistry, Research Center for Eco-Environmental Sciences, Chinese Academy of Sciences, Beijing, 100085, China \\ ${ }^{\mathrm{b}}$ Graduate School of Chinese Academy of Sciences, Beijing 100039, China
}

\section{A R T I C L E I N F O}

\section{Article history:}

Received 15 December 2008

Received in revised form 28 February 2009

Accepted 8 March 2009

Available online 5 April 2009

\section{Keywords:}

Catalysis

Dichloramine

Electron spin resonance (ESR)

Radical intermediates

Water disinfection

\begin{abstract}
A B S T R A C T
The decomposition of monochloramine, which is commonly used as a secondary disinfectant at water treatment plants to reduce the formation of disinfection byproducts, always occurs in water and can be accelerated by certain catalytic substances. This work was to investigate the mechanism of monochloramine decomposition catalyzed by $\mathrm{Cu}$ (II) in aqueous solution. Ultraviolet (UV) spectral results showed that either $\mathrm{Cu}$ (II) addition or $\mathrm{pH}$ decrease would significantly promote the transformation of monochloramine to dichloramine. A copper intermediate, $\mathrm{Cu}(\mathrm{I})$, was extracted from the $\mathrm{NH}_{2} \mathrm{Cl}-\mathrm{Cu}$ (II) solution by solid-phase extraction and identified by X-ray photoelectron spectroscopy (XPS). Electron spin resonance (ESR) results showed that hydroxyl radical $(\cdot \mathrm{OH})$ and amidogen radical $\left(\cdot \mathrm{NH}_{2}\right)$ were generated in the reaction between monochloramine and $\mathrm{Cu}(\mathrm{II})$. These radical intermediates also contributed to monochloramine decomposition. Based on the experimental results, the reaction mechanism for $\mathrm{Cu}(\mathrm{II})$-catalyzed monochloramine decomposition was proposed which consisted of two pathways: 1) direct catalysis in which $\mathrm{Cu}(\mathrm{II})$ acts as a Lewis acid to accelerate monochloramine decomposition to dichloramine (major pathway); and 2) indirect catalysis in which the active radical intermediates $\left(\cdot \mathrm{OH}\right.$ and $\left.\cdot \mathrm{NH}_{2}\right)$ react with monochloramine and lead to its decomposition (minor pathway).
\end{abstract}

(c) 2009 Elsevier B.V. All rights reserved.

\section{Introduction}

In response to the stringent health regulations regarding disinfection byproducts, monochloramine has been utilized as a secondary disinfectant more and more extensively in water treatment (Howard and Inglis, 2005; Duirk and Valentine, 2006; Liu et al., 2006). Monochloramine is nonetheless inherently unstable even without any reactive substance, and decomposes through a complex set of reactions. These reactions ultimately result in the oxidation of ammonia and the reduction of active chlorine (Jafvert and Valentine, 1992). Among these reactions, the transformation of monochloramine into dichloramine, which significantly depends on solution $\mathrm{pH}$, governs the overall rate of monochloramine decomposition. These processes are described in the following proton-catalyzed reactions (Valentine, 1988):

$\mathrm{NH}_{2} \mathrm{Cl}+\mathrm{H}^{+}($or $\mathrm{HA}) \rightleftharpoons \mathrm{NH}_{3} \mathrm{Cl}^{+}+(\mathrm{A})^{-}$

$\mathrm{NH}_{3} \mathrm{Cl}^{+}+\mathrm{NH}_{2} \mathrm{Cl} \rightarrow \mathrm{NHCl}_{2}+\mathrm{NH}_{3}+\mathrm{H}^{+}$

$\mathrm{NH}_{2} \mathrm{Cl}+\mathrm{NHCl}_{2} \rightarrow \mathrm{N}_{2}+3 \mathrm{Cl}^{-}+3 \mathrm{H}^{+}$(fast)

Many efforts have been made to investigate the reactions between monochloramine and organic/inorganic constituents during water

\footnotetext{
* Corresponding author. Tel.: +8610 62849151; fax: +861062923558. E-mail address: jhqu@rcees.ac.cn (J. Qu).
}

disinfection (Wistrom et al., 1996; Vikesland et al., 1998; Brown and Emmert, 2006). Vikesland and Valentine (2000) found that monochloramine can be decomposed by both redox and autocatalytic reductions in the presence of $\mathrm{Fe}(\mathrm{II})$. The autocatalytic mechanism involves the formation of amidogen radical $\left(\cdot \mathrm{NH}_{2}\right)$ as an intermediate. Previous studies also showed that electron transfer processes may produce some radicals (e.g., $\cdot \mathrm{OH}$ and $\cdot \mathrm{NH}_{2}$ ) along with hydrated electrons and various other intermediate species (Johnson et al., 2002). The reaction mechanisms of monochloramine with these intermediates have been specifically investigated (Johnson et al., 2002; Poskrebyshev et al., 2003). Monochloramine can react with hydrated electrons very rapidly via single electron reduction to produce $\cdot \mathrm{NH}_{2}$ (Eq. (4)). Monochloramine can also react with $\cdot \mathrm{OH}$ to produce $\cdot \mathrm{NHCl}$ and $\cdot \mathrm{NH}_{2}$ (Eqs. (5)-(7)). Both $\cdot \mathrm{NH}_{2}$ and $\cdot \mathrm{NHCl}$ extinguish in radical-radical merging reactions. These processes occur concurrently and may involve complex and interrelated pathways.

$\mathrm{NH}_{2} \mathrm{Cl}+\mathrm{e}_{\mathrm{aq}}^{-} \rightarrow \cdot \mathrm{NH}_{2}+\mathrm{Cl}^{-}$

$\mathrm{NH}_{2} \mathrm{Cl}+\cdot \mathrm{OH} \rightarrow \cdot \mathrm{NH}_{2}+\mathrm{HClO}$

$\mathrm{NH}_{2} \mathrm{Cl}+\cdot \mathrm{OH} \rightleftharpoons \cdot \mathrm{NHCl}+\mathrm{H}_{2} \mathrm{O}$

Copper, mainly presents as $\mathrm{Cu}(\mathrm{II})$, can act as heterogeneous or homogeneous catalyst in many reactions. It was reported that $\mathrm{Cu}$ (II) could catalyze sodium hypochlorite decomposition in alkaline solutions (Gray et al., 1977; Church, 1994). Cu(II) could also catalyze the decomposition of monochloramine in drinking water, and its catalytic 
effect increased as the solution pH decreased (Fu et al., 2009). However, the catalytic mechanism of $\mathrm{Cu}$ (II) on monochloramine decomposition still remains largely unknown.

Similar to the catalytic effect of $\mathrm{Fe}(\mathrm{II})$ on monochloramine decomposition, it is hypothesized that $\mathrm{Cu}(\mathrm{II})$ may also react with monochloramine via electron transfer to produce $\cdot \mathrm{NH}_{2}$. Meanwhile, the oxidation state of copper may vary from $\mathrm{Cu}$ (II) to $\mathrm{Cu}$ (I) or $\mathrm{Cu}$ (III) correspondingly. The objective of this work was to elucidate the reaction mechanism of monochloramine decomposition catalyzed by $\mathrm{Cu}(\mathrm{II})$. The transformation of $\mathrm{Cu}(\mathrm{II})$ species was examined by X-ray photoelectron spectroscopy (XPS), and the generation of radical intermediates was detected by electron spin resonance (ESR).

\section{Materials and methods}

\subsection{Chemicals}

Reaction solutions were all prepared with deionized water produced by a Barnstead ULTRO pure water system with a resistivity greater than $18 \mathrm{M} \Omega \mathrm{cm}$. $\mathrm{Cu}^{\mathrm{I}} \mathrm{Br}(\geq 98.5 \%)$ was stored in a nitrogen-filled exsiccator in the dark to prevent moisture and light. Ethylenediamine ( $\geq 99 \%$ ), $\mathrm{NaCl}$ ( $\geq 99.5 \%$ Suprapur), borate ( $\geq 99.99 \%$, Suprapur), and $\mathrm{HCl}$ (30\%, Suprapur) were purchased from Beijing Chemical Co. (Beijing, China). Bathocuproine disulfonic acid disodium salt (2, 9dimethyl-4, 7-diphenyl-1, 10-phenanthroline disulfonic acid disodium salt, 97\%) was obtained from Acros (NJ, USA). All glassware was soaked in a concentrated chlorine solution (about $5000 \mathrm{mg} \mathrm{L}^{-1}$ as $\mathrm{Cl}_{2}$ ) for at least $24 \mathrm{~h}$, rinsed with deionized water, and dried at $105^{\circ} \mathrm{C}$ before use.

\subsection{Preparation of $\mathrm{NH}_{2} \mathrm{Cl}$ solution}

The stock solution of monochloramine was prepared by adding sodium hypochlorite solution to a well-stirred solution of ammonium chloride at a $\mathrm{Cl}_{2} / \mathrm{N}$ molar ratio of 0.65 , and its $\mathrm{pH}$ was immediately adjusted to 8.0 by $\mathrm{NaOH}$. The working solutions of monochloramine were prepared by diluting the stock to desired concentrations. The concentration of monochloramine was measured with the DPD-FAS titrimetric method. $\mathrm{KH}_{2} \mathrm{PO}_{4}$ of $10 \mathrm{mM}$ was used to buffer all the reaction solutions. All reactions were carried out at a constant temperature of $25^{\circ} \mathrm{C}$.

\subsection{Solid phase extraction (SPE) of $\mathrm{Cu}(\mathrm{I})$}

Following the previous studies (Moffett et al., 1985; BuergeWeirich and Sulzberger, 2004), bathocuproine was selected as a chelator for $\mathrm{Cu}(\mathrm{I})$ and ethylenediamine as a masking ligand for $\mathrm{Cu}$ (II). The $\mathrm{NH}_{2} \mathrm{Cl}-\mathrm{Cu}$ (II) solution $(1000 \mathrm{~mL}$ ) was mixed with the bathocuproine/ethylenediamine/borate (BEB) solution $(1000 \mathrm{~mL})$ that approximately contained $1 \mu \mathrm{M}$ bathocuproine, $1 \mu \mathrm{M}$ ethylenediamine, and $10 \mathrm{mM}$ borate. The resulting $\mathrm{Cu}(\mathrm{I})-\mathrm{BEB}$ solution was allowed to equilibrate for $3 \mathrm{~h}$ in the dark for sufficient exchange of $\mathrm{Cu}(\mathrm{I})$ between bathocuproine and other ligands. The stock solution of bathocuproine disulfonic acid disodium salt $(10 \mathrm{mM})$ was freshly prepared prior to preparing the BEB solution.

$\mathrm{Cu}(\mathrm{I})$-bathocuproine complex was solid-phase extracted with $\mathrm{C} 18$ column. The appearance of a single, narrow and orange-colored band in the C18 column, through which the sample passed, would denote the successful extraction of $\mathrm{Cu}(\mathrm{I})$ (Moffett et al., 1985).

\subsection{XPS analysis}

XPS analysis was performed using a PHI Quantera SXM spectrometer with monochromatic $\mathrm{Al} \mathrm{K} \alpha$ radiation. The $\mathrm{C} 1 \mathrm{~s}$ peak was selected as an inner standard calibration peak at $284.8 \mathrm{eV}$. XPS data were processed using a nonlinear least-square fitting program (XPSpeak software 4.1, Raymund W. M. K. Work).

\subsection{ESR analysis}

Radical intermediates were detected using a Bruker ESP-300E ESR spectrometer which was operated at $9.79 \mathrm{GHz}$ with $100 \mathrm{kHz}$ modulation, $0.5 \mathrm{G}$ modulation amplitude, $2.5 \times 10^{5}$ gain, $39.9 \mathrm{~mW}$ microwave power, $40.96 \mathrm{~ms}$ time constant, $80 \mathrm{G} / 84 \mathrm{~s}$ sweep rate and $80 \mathrm{G}$ sweep width. The solution of 5,5-dimethylpyrroline-N-oxide (DMPO, $50 \mathrm{mM}$ ) was used as spin trap for radicals. After the DMPO solution was mixed with monochloramine solution, $\mathrm{Cu}(\mathrm{II})$ was added to initiate the reaction. The time between the reaction initiation and the onset of ESR scanning was controlled for less than 2 min.

The effect of solution $\mathrm{pH}$ on radical intensity was investigated according to the following procedures: 1 ) prepare a working solution containing $0.9 \mathrm{mM} \mathrm{NH}_{2} \mathrm{Cl}, 50 \mathrm{mM}$ DMPO and $10 \mathrm{mM}$ phosphate as buffer; 2 ) adjust the solution $\mathrm{pH}$ to a desired value (i.e., 5.8, 6.6, 7.9); 3 ) add $0.1 \mathrm{mM} \mathrm{Cu}(\mathrm{II})$ into the working solution to initiate the reaction; and 4) immediately analyze the radical intensity with ESR.

The effect of $\mathrm{Cu}(\mathrm{II}) / \mathrm{NH}_{2} \mathrm{Cl}$ molar ratio on radical intensity was examined following the procedures: 1) prepare a working solution containing $0.9 \mathrm{mM} \mathrm{NH}_{2} \mathrm{Cl}, 50 \mathrm{mM}$ DMPO and $10 \mathrm{mM}$ phosphate as buffer; 2 ) adjust its $\mathrm{pH}$ to 6.0 ; 3 ) add a desired amount of $\mathrm{Cu}$ (II) (i.e., 0 , $0.09,0.54,0.90$ and $1.35 \mathrm{mM}$ ) into the working solution to initiate the reaction; and 4) immediately analyze the radical intensity with ESR.

\section{Results and discussion}

\subsection{Ultraviolet (UV) spectral characteristics}

UV spectral experiments were conducted to investigate the effects of solution $\mathrm{pH}$ and $\mathrm{Cu}(\mathrm{II})$ on the decomposition of monochloramine. Monochloramine and dichloramine have a characteristic absorption peak at $245 \mathrm{~nm}$ and $294 \mathrm{~nm}$, respectively (Hand and Margerum, 1983; Valentine et al., 1986).

Fig. 1a showed the variation of UV spectra of $1 \mathrm{mM}$ monochloramine solution as $\mathrm{pH}$ was continuously adjusted downward from 7.3 to 3.5. The pH adjustment and UV scan were finished within $5 \mathrm{~min}$. Results indicated that as the solution $\mathrm{pH}$ decreased, the $245-\mathrm{nm}$ peak (denoting monochloramine) intensity gradually decreased while the 294-nm peak (denoting dichloramine) intensity increased accordingly. It implies that the decrease of $\mathrm{pH}$ would accelerate the decomposition of monochloramine to dichloramine. This result agrees well with the literature information (Qiang and Adams, 2004).

Fig. 1b showed the variation of UV spectra of the $\mathrm{NH}_{2} \mathrm{Cl}-\mathrm{Cu}$ (II) reaction system as a function of reaction time. The concentration of monochloramine was prepared at $1 \mathrm{mM}$ with solution $\mathrm{pH}$ maintained at $6.0 \times 10 \mathrm{mM}$ phosphate buffer, then $10 \mathrm{mg} \mathrm{L}^{-1} \mathrm{Cu}(\mathrm{II})$ was introduced. Results indicated that the intensity of the monochloramine peak $(245 \mathrm{~nm})$ notably decreased and the dichloramine peak emerged at $294 \mathrm{~nm}$ upon the addition of $\mathrm{Cu}(\mathrm{II})$. As the reaction proceeded, the intensities of both monochloramine and dichloramine peaks attenuated. It is seen that although dichloramine was continuously produced from monochloramine decomposition, its own decomposition rate outweighed its formation rate.

Valentine (1988) reported that the disproportionation of monochloramine, which resulted in the formation of dichloramine, was a general acid-catalyzed process. The resulting dichloramine decomposed rapidly via a series of redox reactions, leading to more monochloramine decomposition in turn. The UV spectral results clearly indicated that $\mathrm{Cu}(\mathrm{II})$ could serve as a Lewis acid, similar to $\mathrm{H}^{+}$, to catalytically promote the disproportionative decomposition of monochloramine.

\subsection{Copper species transformation}

SPE and XPS methods were utilized together to investigate copper species transformation during the reaction between monochloramine 

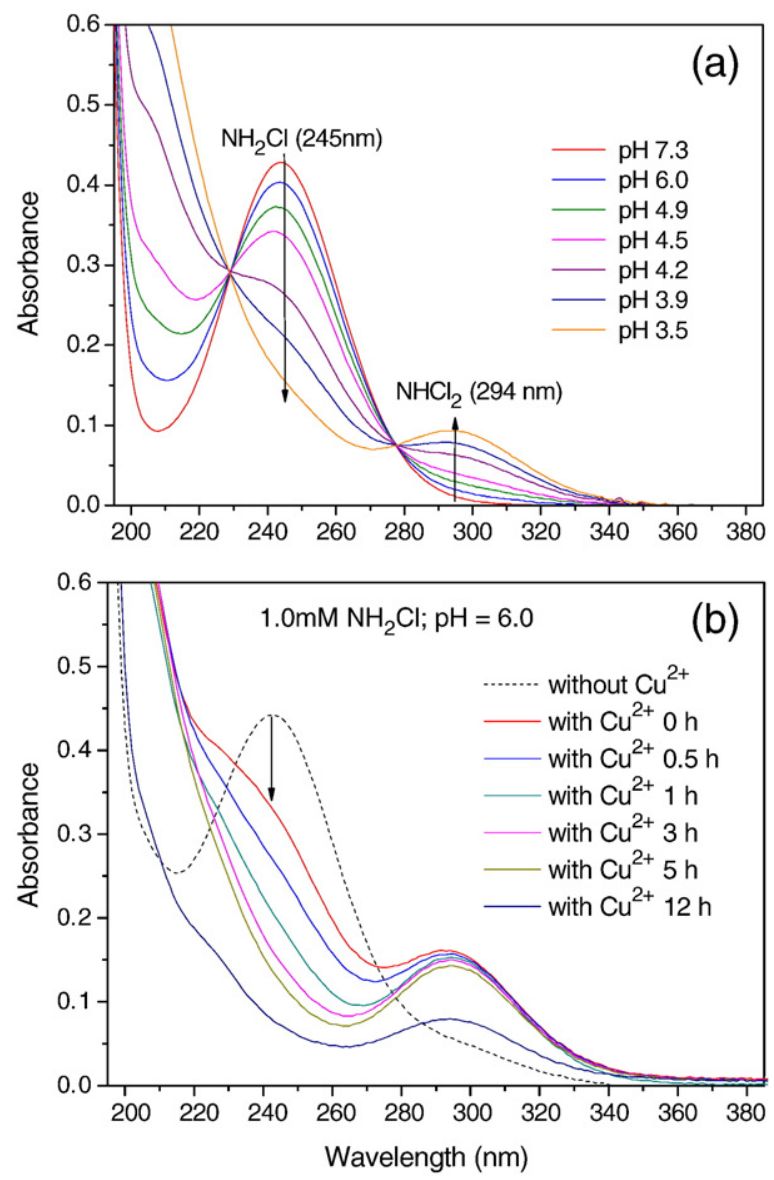

Fig. 1. Variation of UV spectra of: (a) $\mathrm{NH}_{2} \mathrm{Cl}$ solution as $\mathrm{pH}$ was adjusted downward in the absence of $\mathrm{Cu}(\mathrm{II})$; and (b) the $\mathrm{NH}_{2} \mathrm{Cl}-\mathrm{Cu}$ (II) reaction system at $\mathrm{pH} 6.0$ as reaction time extended, $\left[\mathrm{NH}_{2} \mathrm{Cl}\right]_{\mathrm{o}}=1.0 \mathrm{mM},[\mathrm{Cu}(\mathrm{II})]_{\mathrm{o}}=10 \mathrm{mg} \mathrm{L}^{-1}$.

and $\mathrm{Cu}(\mathrm{II})$. After the sample passed through the $\mathrm{C} 18$ column, a small fraction of the orange-colored band was sliced, freeze-dried, and analyzed by XPS. Fig. 2 compared the XPS spectra of a $\mathrm{Cu}^{\mathrm{I}} \mathrm{Br}$ standard and the Cu-bathocuproine complex extracted from the sample. Results indicated that both spectra had two peaks at the same binding energies of 932.3 and $952.2 \mathrm{eV}$. It was thus confirmed that $\mathrm{Cu}(\mathrm{I})$ was generated via electron transfer step during the reaction between monochloramine and $\mathrm{Cu}(\mathrm{II})$.

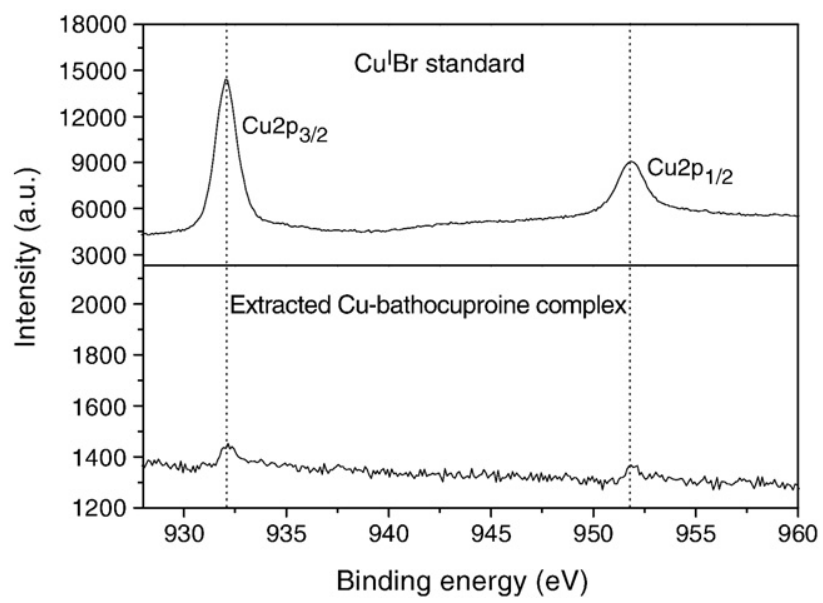

Fig. 2. $\mathrm{Cu} 2 \mathrm{p}$ core level photoelectron spectra of $\mathrm{Cu}^{\mathrm{I}} \mathrm{Br}$ standard and $\mathrm{Cu}$-bathocuproine complex extracted from the $\mathrm{NH}_{2} \mathrm{Cl}-\mathrm{Cu}(\mathrm{II})$ reaction system.

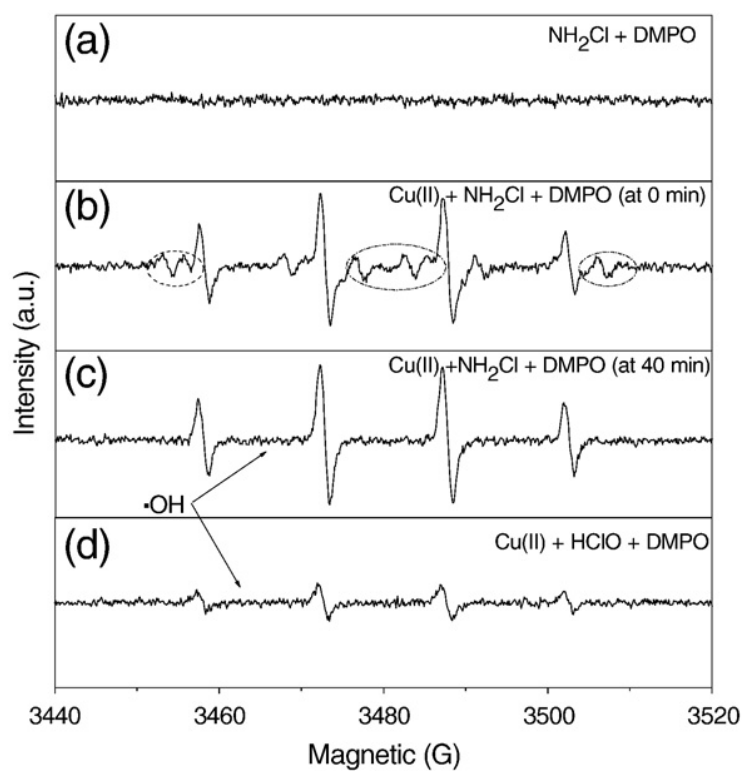

Fig. 3. Comparison of ESR spectra of different reaction systems: (a) $\mathrm{NH}_{2} \mathrm{Cl}+\mathrm{DMPO}$; (b) $\mathrm{Cu}(\mathrm{II})+\mathrm{NH}_{2} \mathrm{Cl}+\mathrm{DMPO}$ (at 0 min); (c) $\mathrm{Cu}$ (II) $+\mathrm{NH}_{2} \mathrm{Cl}+\mathrm{DMPO}$ (at $40 \mathrm{~min}$ ); and (d) $\mathrm{Cu}$ (II) $+\mathrm{HClO}+$ DMPO. Experimental conditions: $\left[\mathrm{NH}_{2} \mathrm{Cl}\right]_{\mathrm{o}}=0.9 \mathrm{mM},[\mathrm{Cu}(\mathrm{II})]_{\mathrm{o}}=0.9 \mathrm{mM}$, $[\mathrm{HClO}]_{\mathrm{o}}=0.9 \mathrm{mM},[\mathrm{DMPO}]_{\mathrm{o}}=50 \mathrm{mM}, \mathrm{pH}=6.0$.

\subsection{Detection of active radical intermediates}

ESR was employed to detect the active radical intermediates produced in the reaction system of $\mathrm{NH}_{2} \mathrm{Cl}-\mathrm{Cu}(\mathrm{II})$. Results indicated that in the absence of $\mathrm{Cu}(\mathrm{II})$, no radical signal was detected in the $\mathrm{NH}_{2} \mathrm{Cl}$ solution (Fig. 3a). Right after $\mathrm{Cu}$ (II) addition, however, radical signals appeared and a part of which was identified to result from $\cdot \mathrm{OH}$ according to Paciolla et al. (1999) (Fig. 3b). Moreover, there existed other radical signals (Fig. 3b) which eventually disappeared after the $\mathrm{NH}_{2} \mathrm{Cl}-\mathrm{Cu}$ (II) reaction was allowed to proceed for $40 \mathrm{~min}$ (Fig. 3c). It was suspected that these signals might come from a radical intermediate generated from the reaction between $\mathrm{Cu}(\mathrm{II})$ and hypochlorous acid $(\mathrm{HClO})$, a trace byproduct produced from the reaction of monochloramine with $\cdot \mathrm{OH}$ (Eq. (5)) or from monochloramine hydrolysis (Eq. (7)). However, the experimental results showed that only $\cdot \mathrm{OH}$ signals were detected with a much lower intensity in the reaction system of $\mathrm{HClO}-\mathrm{Cu}$ (II) (Fig. 3d). It was reported that the reaction between hypochlorous acid and metal ions may produce $\cdot \mathrm{OH}$ (Koppenol and Butler, 1985; Folkes et al., 1995).

$\mathrm{NH}_{2} \mathrm{Cl}+\mathrm{H}_{2} \mathrm{O} \rightleftharpoons \mathrm{HClO}+\mathrm{NH}_{3}$

To identify the unknown signals above, a standard $\cdot \mathrm{NH}_{2}$ radical was generated by the reaction system of $\mathrm{NH}_{2} \mathrm{Cl}-\mathrm{Fe}$ (II) $(0.9 \mathrm{mM}$ each) according to Vikesland and Valentine (2000) and its signals were recorded by ESR (Fig. 4a). In addition, the $\cdot \mathrm{OH}$ signals were eliminated by subtracting the ESR spectrum of Fig. $3 \mathrm{c}$ from that of Fig. $3 \mathrm{~b}$. The resulting spectrum (Fig. $4 \mathrm{~b}$ ), compared to that of the standard $\cdot \mathrm{NH}_{2}$ radical (Fig. 4a), confirmed the formation of $\cdot \mathrm{NH}_{2}$ in the reaction system of $\mathrm{NH}_{2} \mathrm{Cl}-\mathrm{Cu}$ (II) (Fig. 3b). Therefore, two active radical intermediates, $\cdot \mathrm{OH}$ and $\cdot \mathrm{NH}_{2}$, were generated when monochloramine reacted with $\mathrm{Cu}(\mathrm{II})$. Upon formation, $\cdot \mathrm{OH}$ could maintain a strong intensity for a longer time than $\cdot \mathrm{NH}_{2}$ in the reaction solution (Fig. $3 \mathrm{~b}$ and c).

The effect of solution $\mathrm{pH}$ on the intensity of active radical intermediates was studied in the $\mathrm{pH}$ range from 5.8 to 7.9. Results indicate that the radical intensity significantly decreased with the increase of $\mathrm{pH}$ (Fig. 5a). More than $80 \%$ of the radical intermediates disappeared in the $\mathrm{NH}_{2} \mathrm{Cl}-\mathrm{Cu}$ (II) reaction system as the solution $\mathrm{pH}$ was raised from 5.8 to 7.9 . It is seen that the formation of active radical 


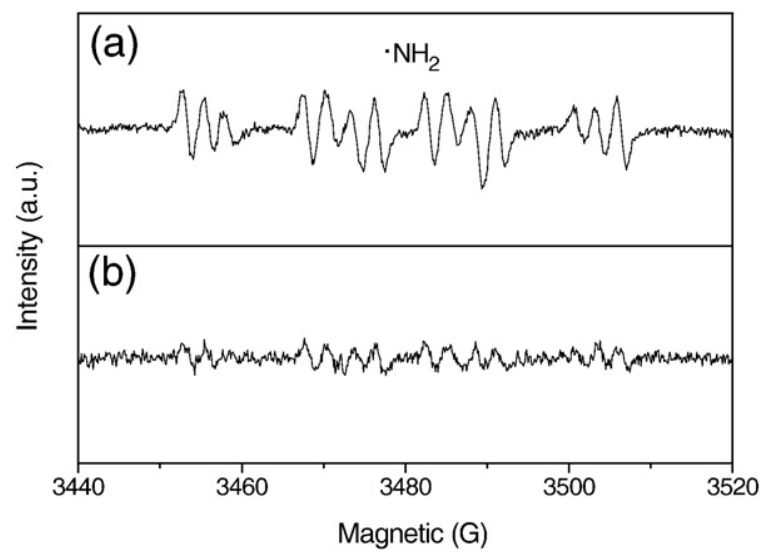

Fig. 4. Identification of $\cdot \mathrm{NH}_{2}$ intermediate: (a) ESR spectrum of the standard $\cdot \mathrm{NH}_{2}$ generated in the reaction system of $0.9 \mathrm{mM} \mathrm{Fe}(\mathrm{II})+0.9 \mathrm{mM} \mathrm{NH}_{2} \mathrm{Cl}+50 \mathrm{mM}$ DMPO; and (b) derived ESR spectrum (Fig. 3b-c).

intermediates was highly $\mathrm{pH}$ dependent. Fig. $5 \mathrm{~b}$ showed the effect of $\mathrm{Cu}(\mathrm{II}) / \mathrm{NH}_{2} \mathrm{Cl}$ molar ratio on the intensity of active radical intermediates at $\mathrm{pH}$ 6.0. The initial concentration of monochloramine was maintained constant at $0.9 \mathrm{mM}$, while the $\mathrm{Cu}(\mathrm{II}) / \mathrm{NH}_{2} \mathrm{Cl}$ molar ratio ranged from 0 to 1.5 by varying the initial concentration of $\mathrm{Cu}(\mathrm{II})$. Results indicated that the radical intensity reached maximum at the molar ratio of $\mathrm{Cu}(\mathrm{II}) / \mathrm{NH}_{2} \mathrm{Cl}$ equaling 1.0 , and either decreasing or increasing this molar ratio would reduce the formation of active radicals.
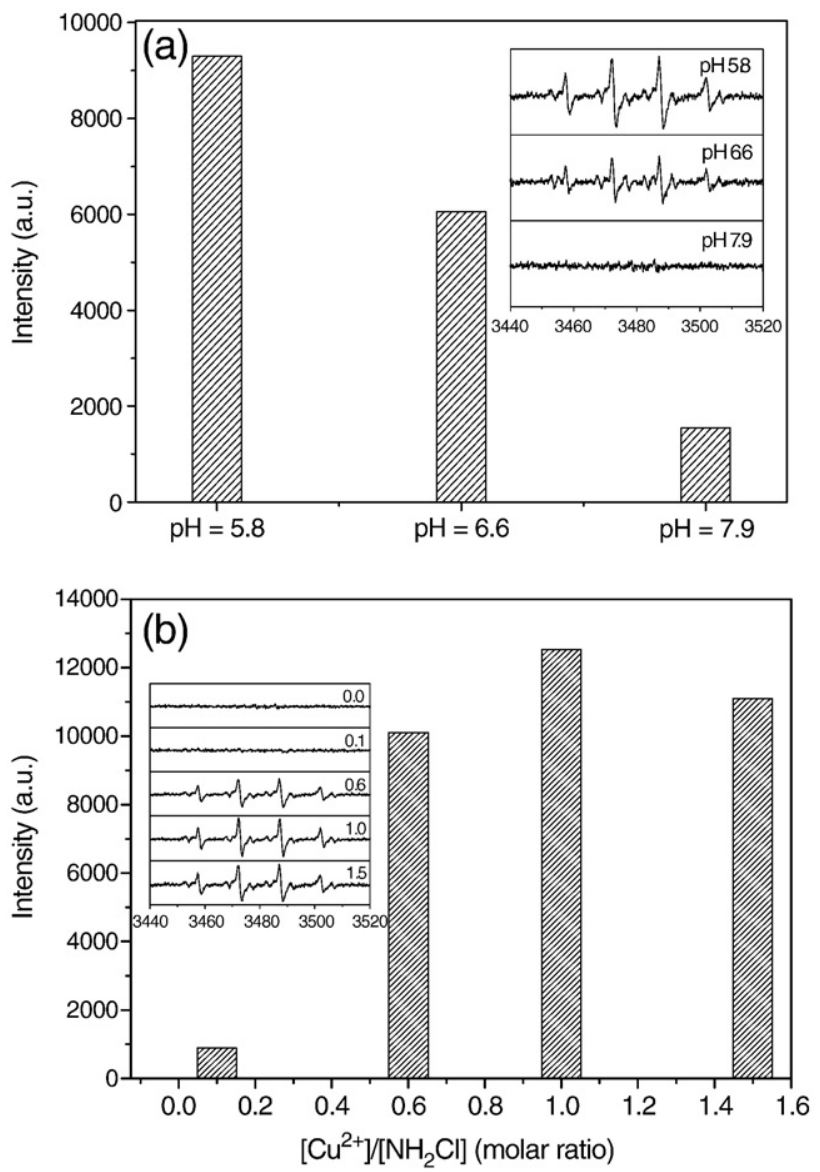

Fig. 5. Initial intensity of active radical intermediates as a function of: (a) solution $\mathrm{pH}$ in the reaction system of $0.1 \mathrm{mM} \mathrm{Cu}(\mathrm{II})+0.9 \mathrm{mM} \mathrm{NH}_{2} \mathrm{Cl}+50 \mathrm{mM}$ DMPO; (b) molar ratio of $[\mathrm{Cu}(\mathrm{II})] /\left[\mathrm{NH}_{2} \mathrm{Cl}\right]$ at $\mathrm{pH} 6.0,\left[\mathrm{NH}_{2} \mathrm{Cl}\right]_{\mathrm{o}}=0.9 \mathrm{mM}$.

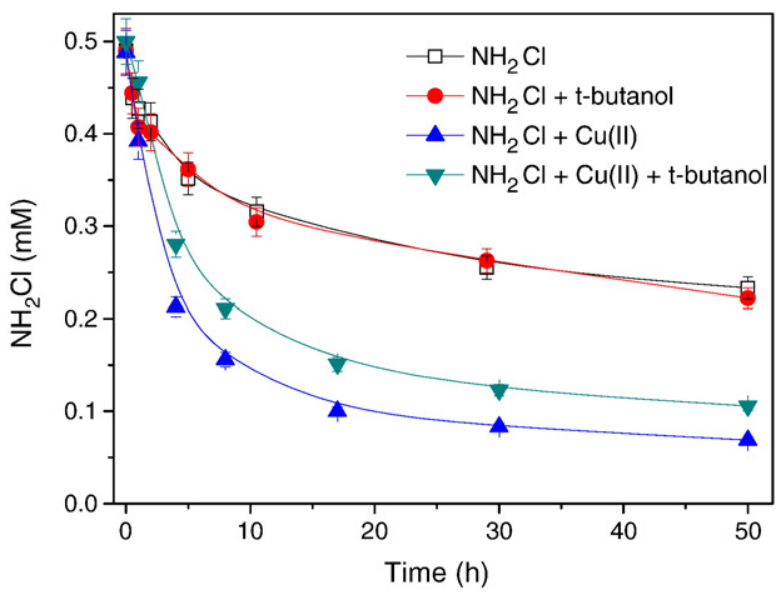

Fig. 6. Effect of tert-butanol on monochloramine decomposition in the absence or presence of $\mathrm{Cu}(\mathrm{II})$. Experimental conditions: $\left[\mathrm{NH}_{2} \mathrm{Cl}\right]_{\mathrm{o}}=0.5 \mathrm{mM},\left[\mathrm{Cu}^{2+}\right]_{\mathrm{o}}=10 \mathrm{mg} \mathrm{L}^{-1}$, [tert-butanol] $=5 \mathrm{mM}, \mathrm{pH}=6.0$.

\subsection{Effect of radicals on monochloramine decomposition}

To assess the effect of active radical intermediates on $\mathrm{Cu}(\mathrm{II})$ catalyzed monochloramine decomposition, tert-butanol was selected as the radical scavenger. Tert-butanol can react rapidly with radicals to generate inert intermediates, thus terminating radical chain reactions (Ma and Graham, 2000).

Fig. 6 showed that monochloramine attenuated naturally in water with about $50 \%$ loss after a reaction time of $50 \mathrm{~h}$. The addition of tertbutanol into monochloramine solution had no effect on the monochloramine decomposition rate. In the reaction system of $\mathrm{NH}_{2} \mathrm{Cl}-\mathrm{Cu}$ (II), $\mathrm{Cu}(\mathrm{II})$ significantly enhanced the decomposition rate of monochloramine as compared to the natural attenuation curve above. If tert-butanol was added into the $\mathrm{NH}_{2} \mathrm{Cl}-\mathrm{Cu}$ (II) system to scavenge the active radical intermediates (i.e., $\cdot \mathrm{OH}$ and $\cdot \mathrm{NH}_{2}$ ), the monochloramine decomposition rate was decreased but still much faster than its natural attenuation rate. The applied concentration of tert-butanol was $5 \mathrm{mM}$ that was enough to scavenge all the active radical intermediates produced in the reaction system. Results indicated that $85 \%$ of monochloramine was lost in the $\mathrm{NH}_{2} \mathrm{Cl}-\mathrm{Cu}$ (II) system as compared to the $77 \%$ loss in the presence of tert-butanol. It is noted that all the reaction curves approached parallel after approximately $10 \mathrm{~h}$, implying that both $\mathrm{Cu}(\mathrm{II})$ and the radical intermediates promoted monochloramine decomposition only in the early period of reaction. Thereafter, the natural attenuation started to govern monochloramine decomposition. Results also revealed that the direct catalysis induced by $\mathrm{Cu}(\mathrm{II})$ on monochloramine decomposition

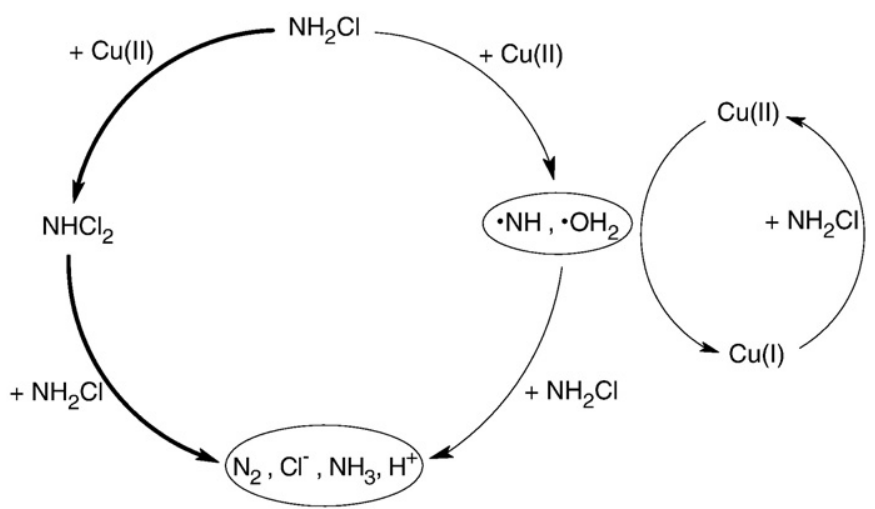

Fig. 7. Proposed reaction mechanism for $\mathrm{Cu}(\mathrm{II})$-catalyzed monochloramine decomposition. 
significantly outweighed the indirect catalysis induced by the active radical intermediates.

\subsection{Proposed reaction mechanism}

Based on the experimental results described above, the decomposition of monochloramine in the presence of $\mathrm{Cu}(\mathrm{II})$ was accelerated by the direct catalysis of $\mathrm{Cu}$ (II) and the indirect catalysis of the active radical intermediates, $\cdot \mathrm{OH}$ and $\cdot \mathrm{NH}_{2}$. The proposed reaction mechanism is illustrated in Fig. 7 and detailed below.

The direct catalysis of $\mathrm{Cu}$ (II) made a major contribution to monochloramine decomposition. Similar to the proton-catalyzed process, in which monochloramine auto-decomposes through disproportionation to form dichloramine (Valentine, 1988), $\mathrm{Cu}(\mathrm{II})$ could act as a Lewis acid to enhance monochloramine decomposition to dichloramine (Eqs. (8)-(9)). Dichloramine further reacted with monochloramine to the end products such as $\mathrm{N}_{2}, \mathrm{Cl}^{-}, \mathrm{NH}_{3}$, and $\mathrm{H}^{+}$ (Eq. (3)).

The indirect catalysis of active radical intermediates made a comparatively minor contribution to monochloramine decomposition (as shown in Fig. 6). The addition of $\mathrm{Cu}$ (II) into the monochloramine solution would initiate a series of redox reactions in which the active radical intermediates, mainly including $\cdot \mathrm{OH}$ and $\cdot \mathrm{NH}_{2}$, were generated. Both $\cdot \mathrm{OH}$ and $\cdot \mathrm{NH}_{2}$ were identified by ESR in this study. These radical intermediates further reacted with monochloramine to eventually produce the end products (Eqs. (5)-(6)).

In addition, our previous study (Fu et al., 2009) has shown that the complexation between $\mathrm{Cu}(\mathrm{II})$ and monochloramine led to the formation of $\mathrm{Cu}(\mathrm{I})$ (Eq. (10)), which was identified by the integrated method of SPE and XPS in this work. $\mathrm{Cu}(\mathrm{I})$ could in turn react with $\mathrm{NH}_{2} \mathrm{Cl}$ to form $\cdot \mathrm{NH}_{2}$ and $\mathrm{Cu}(\mathrm{II})$ was regenerated (Eq. (10)). Disintegration of the $\left[\mathrm{Cu}^{\mathrm{II}} \mathrm{NH}_{2} \mathrm{Cl}\right]^{2+}$ complex also yielded another product, $\cdot \mathrm{NHCl}$ radical, which could hydrolyze to form $\cdot \mathrm{OH}$ (Eq. (6)).

$\mathrm{Cu}^{2+}+\mathrm{NH}_{2} \mathrm{Cl} \rightarrow\left[\mathrm{Cu}^{\mathrm{II}} \mathrm{NH}_{2} \mathrm{Cl}\right]^{2+}$ (complex)

$\left[\mathrm{Cu}^{\mathrm{II}} \mathrm{NH}_{2} \mathrm{Cl}\right]^{2+}+\mathrm{NH}_{2} \mathrm{Cl} \rightarrow \mathrm{NHCl}_{2}+\mathrm{NH}_{3}+\mathrm{Cu}^{2+}$

$\left[\mathrm{Cu}^{\mathrm{II}} \mathrm{NH}_{2} \mathrm{Cl}\right]^{2+} \rightarrow \mathrm{Cu}^{+}+\cdot \mathrm{NHCl}+\mathrm{H}^{+}$

$\mathrm{Cu}^{+}+\mathrm{NH}_{2} \mathrm{Cl} \rightarrow \mathrm{Cu}^{2+}+\cdot \mathrm{NH}_{2}+\mathrm{Cl}^{-}$

It was reported that $\cdot \mathrm{NH}_{2}$ was generated in the reaction system of $\mathrm{NH}_{2} \mathrm{Cl}-\mathrm{Fe}$ (II) (Vikesland and Valentine, 2000). Therefore, it is reasonable to expect that $\cdot \mathrm{NH}_{2}$ was generated, analogously, in the reaction system of $\mathrm{NH}_{2} \mathrm{Cl}-\mathrm{Cu}(\mathrm{I})$ (Eq. (11)). The $\cdot \mathrm{NH}_{2}$ radical could also be generated from the reaction between monochloramine and $\cdot \mathrm{OH}$ (Eq. (5)). The self-merging reaction between the $\mathrm{NH}_{2}$ radicals led to the production of hydrazine (Eq. (12)) (Neta et al., 1988). Upon formation, hydrazine would react rapidly with monochloramine to produce nitrogen gas and ammonium chloride (Sisler et al., 1954; Sanftner et al., 1955):

$$
\begin{aligned}
& \cdot \mathrm{NH}_{2}+\cdot \mathrm{NH}_{2} \rightarrow \mathrm{N}_{2} \mathrm{H}_{4} \\
& \mathrm{~N}_{2} \mathrm{H}_{4}+2 \mathrm{NH}_{2} \mathrm{Cl} \rightarrow \mathrm{N}_{2}+2 \mathrm{NH}_{4}^{+}+2 \mathrm{Cl}^{-}
\end{aligned}
$$

\section{Conclusions}

This work investigated the mechanism of monochloramine decomposition catalyzed by $\mathrm{Cu}(\mathrm{II})$ in water. The experimental results indicated that both $\mathrm{Cu}(\mathrm{II})$ addition and $\mathrm{pH}$ decrease would enhance the decomposition of monochloramine to dichloramine. $\mathrm{Cu}(\mathrm{I})$, which was identified by XPS, and two active radicals $\left(\cdot \mathrm{OH}\right.$ and $\left.\cdot \mathrm{NH}_{2}\right)$, which were identified by ESR, were major intermediates in the reaction system of $\mathrm{NH}_{2} \mathrm{Cl}-\mathrm{Cu}$ (II). In addition, the radical scavenging experiments indicated that $\mathrm{Cu}(\mathrm{II})$ contributed more to monochloramine decomposition than the active radicals. Thus, the catalytic mechanism of $\mathrm{Cu}$ (II) on monochloramine decomposition was proposed to consist of a major direct catalysis pathway, in which $\mathrm{Cu}(\mathrm{II})$ acts as a Lewis acid to enhance monochloramine transformation to dichloramine, and a minor indirect catalysis pathway, in which the active radical intermediates $\left(\cdot \mathrm{OH}\right.$ and $\left.\cdot \mathrm{NH}_{2}\right)$ react with monochloramine thus resulting in more monochloramine loss.

\section{Acknowledgements}

The authors greatly appreciate the financial support from the National Natural Science Foundation of China (Grant No. 50538090) and the Ministry of Science and Technology of China, National Key Technologies R\&D Program (Grant No. 2006BAB17B03).

\section{References}

Brown MA, Emmert GL. On-line monitoring of trihalomethane concentrations in drinking water distribution systems using capillary membrane sampling-gas chromatography. Anal Chim Acta 2006;555:75-83.

Buerge-Weirich D, Sulzberger B. Formation of $\mathrm{Cu}(\mathrm{I})$ in estuarine and marine waters: application of a new solid-phase extraction method to measure $\mathrm{Cu}(\mathrm{I})$. Environ Sci Technol 2004;38:1843-8.

Church JA. Kinetics of the uncatalyzed and copper(II)-catalyzed decomposition of sodium hypochlorite. Ind Eng Chem Res 1994;33:239-45.

Duirk SE, Valentine RL. Modeling dichloroacetic acid formation from the reaction of monochloramine with natural organic matter. Water Res 2006;40:2667-74.

Folkes LK, Candeias LP, Wardman P. Kinetics and mechanisms of hypochlorous acid reactions. Arch Biochem Biophys 1995;323:120-6.

Fu J, Qu JH, Liu RP, Zhao X, Qiang ZM. The influence of $\mathrm{Cu}(\mathrm{II})$ on the decay of monochloramine. Chemosphere 2009;74:181-6.

Gray ET, Taylor RW, Margerum DW. Kinetics and mechanisms of the copper-catalyzed decomposition of hypochlorite and hypobromite. Properties of a dimeric copper (III) hydroxide intermediate. Inorg Chem 1977;16:3047-55.

Hand VC, Margerum DW. Kinetics and mechanisms of the decomposition of dichloramine in aqueous solution. Inorg Chem 1983;22:1449-56.

Howard K, Inglis TJJ. Disinfection of Burkholderia pseudomallei in potable water. Water Res 2005:39:1085-92.

Jafvert CT, Valentine RL. Reaction scheme for the chlorination of ammoniacal water. Environ Sci Technol 1992;26:577-86.

Johnson HD, Cooper WJ, Mezyk SP, Bartels DM. Free radical reactions of monochloramine and hydroxylamine in aqueous solution. Radiat Phys Chem 2002;65:317-26.

Koppenol WH, Butler J. Energetics of interconversion reactions of oxyradicals. Adv Free Radical Bio 1985;1:91-131.

Liu W, Cheung LM, Yang X, Shang C. THM, HAA and CNCl formation from UV irradiation and chlor(am)ination of selected organic waters. Water Res 2006;40:2033-43.

Ma J, Graham NJD. Degradation of atrazine by manganese-catalysed ozonationinfluence of radical scavengers. Water Res 2000;34:3822-8.

Moffett JW, Zika RG, Petasne RG. Evaluation of bathocuproine for the spectrophotometric determination of copper(I) in copper redox studies with applications in studies of natural waters. Anal Chim Acta 1985;175:171-9.

Neta P, Huie RE, Ross AB. Rate constants for reactions of inorganic radicals in aqueous solution. J Phys Chem Ref Data 1988;17:1027-284.

Paciolla MD, Davies G, Jansen SA. Generation of hydroxyl radicals from metal-loaded humic acids. Environ Sci Technol 1999;33:1814-8.

Poskrebyshev GA, Huie RE, Neta P. Radiolytic reactions of monochloramine in aqueous solutions. J Phys Chem A 2003;107:7423-8.

Qiang ZM, Adams CD. Determination of monochloramine formation rate constants with stopped-flow spectrophotometry. Environ Sci Technol 2004;38:1435-44.

Sisler HH, Boatman CE, Neth FT, Smith R, Shellman RW, Kelmers D. The chloraminesammonia reaction in pure water and in other solvents. J Am Chem Soc 1954;76:3912-4.

Sanftner RW, Jones MM, Audrieth LF. Metal deactivators in synthesis of hydrazine. Ind Eng Chem 1955;47:1203-6.

Valentine RL. General acid catalysis of monochloramine disproportionation. Environ Sci Technol 1988;22:691-6.

Valentine RL, Brandt KI, Jafvert CT. A spectrophotometric study of the formation of an unidentified monochloramine decomposition product. Water Res 1986;20:1067-74.

Vikesland PJ, Valentine RL. Reaction pathways involved in the reduction of monochloramine by ferrous Iron. Environ Sci Technol 2000;34:83-90.

Vikesland PJ, Ozekin K, Valentine RL. Effect of natural organic matter on monochloramine decomposition: pathway elucidation through the use of mass and redox balances. Environ Sci Technol 1998;32:1409-16.

Wistrom AO, Chou T, Chang DPY, Schroeder ED. A method for measuring haloform formation during wastewater chlorination. Water Res 1996;30:3146-51. 